\title{
Neuroleptic malignant syndrome induced acute renal failure: Is mental retardation an additional risk factor?
}

\author{
Nöroleptik malign sendromun oluşturduğu akut böbrek yetmezliği: Mental \\ gerilik ilave bir risk faktörü mü? \\ Mansur Kayataş*, Ayşe Koçkara, Can Hüzmeli, Ferhan Candan \\ Department of Nephrology (Prof. M. Kayataş, MD, A. Koçkara, MD, C. Hüzmeli, MD, Prof. F. \\ Candan, MD), Cumhuriyet University School of Medicine, TR-58140 Sivas
}

\begin{abstract}
Neuroleptic malignant syndrome is a rare but serious complication of neuroleptic treatment. It is a disorder which is usually characterized by muscle contraction and changes in consciousness, extrapyramidal symptoms, hyperpyrexia and blood pressure irregularities that often depend on the use of conventional antipsychotic drugs. In this case report, we discuss acute renal failure induced by neuroleptic malignant syndrome developing on the basis of chronic kidney disease in a patient with mental retardation.
\end{abstract}

Keywords: Neuroleptic malign syndrome; mental retardation; acute renal failure

Özet

Nöroleptik malign sendrom, nöroleptik tedavinin nadir; ancak, ciddi bir komplikasyonudur. Sıklıkla klasik antipsikotik ilaçların kullanımına bağlı olarak gelişen ekstrapiramidal semptomlar, hiperpreksi, kan basıncında düzensizlikler, genellikle kaslarda kasılma ve bilinçde değişiklikler ile karakterize bir hastalıktır. Bu olgu sunumunda mental gerilik olan bir hastada kronik böbrek hastalığı zemininde gelişen ve nöroleptik malign sendromun oluşturduğu akut böbrek yetmezliğini tartışmaktayız.

Anahtar sözcükler: Nöroleptik malign sendrom, mental gerilik, akut böbrek yetmezliği

Geliş tarihi/Received: January 06, 2012; Kabul tarihi/Accepted: February 3, 2012

\section{*Corresponding author:}

Mansur Kayataş, MD, Nefroloji Bilim Dalı, Cumhuriyet Üniversitesi Tıp Fakültesi, TR-58140, Sivas. E-mail: mansurkay@yahoo.com

\section{Introduction}

Neuroleptic malignant syndrome (NMS), was first described by Delay et. al in 1960 and was defined as a serious and one of the life-threatening side effects of the antipsychotic medication [1]. Patients with high fever and muscle rigidity are in the foreground. Autonomic dysfunction (sweating, tachycardia, labile blood pressure), changes in consciousness, high creatine phosphokinase (CPK) levels, leukocytosis, low iron or potassium levels, and non-specific EEG changes are among the other diagnostic features $[2,3]$. Pathophysiology of NMS is fully elucidated, but it has been suggested that the central dopaminergic hypoactivity plays a major role $[4,5]$. Clinical studies support that the use of high drug doses, parenteral drugs and more potent drugs are facilitators of NMS $[6,7]$. Other potential risk factors are the use of concomitant medications such as lithium or metaklopromid, discontinuation of dopamine agonists, anticholinergic drugs or 
benzodiazepines, presence of organic brain syndrome, extrapyramidal disorders, iron deficiency and dehydration [8]. In the literature, especially mental retardation is reported as a risk factor for recurrent NMS [9]. The frequency of NMS is about 0:02 to 2:44\%, and $10 \%$ of cases result in death category [10-12].

\section{Case report}

Forty-year-old woman with frequent epileptic seizures, high fever $\left(39^{\circ} \mathrm{C}\right)$, convulsions, decreased urine output, nausea and vomiting complaints in the last 3 days was admitted to the emergency department. Her past medical history revealed the presence of febrile illness, both physical and mental retardation and, the use of epileptic drugs for 32 years. Upon admission to the emergency room, she had used oxcarbazepine $300 \mathrm{mg} /$ day, phenytoin $200 \mathrm{mg} /$ day and clonazepam $2 \mathrm{mg} /$ day. Physical examination revealed clear consciousness, agitation, blood pressure of $160 / 100 \mathrm{mmHg}$, fever at $37^{\circ} \mathrm{C}$ and generalized tonic-clonic seizure, respectively.

Laboratory investigation showed BUN: $156 \mathrm{mg} / \mathrm{dL}(5-25 \mathrm{mg} / \mathrm{dL})$, creatinine: $16.6 \mathrm{mg} / \mathrm{dL}$ (0.4-1 mg/dL), Na: $140 \mathrm{mmoL} / \mathrm{L}$ (136-148 mmoL/L), K: $3.1 \mathrm{mmoL} / \mathrm{L}(3.6-5.1 \mathrm{mmoL} / \mathrm{L})$, $\mathrm{Cl}: 100.6 \mathrm{mmoL} / \mathrm{L}(101-111 \mathrm{mmoL} / \mathrm{L})$, venous bicarbonate: $16 \mathrm{mmoL} / \mathrm{L}(22-29$ mmoL/Ll), uric acid: $9.4 \mathrm{mg} / \mathrm{dL}$ (2.6-8 mg/dL), LDH: $419 \mathrm{IU} / \mathrm{L}$ (98-192 IU/L), ALT: 25 IU/L (5-54 IU/L), AST: 41 IU/L (5-40 IU/L), GGT: 172 IU/L(70-50 IU/L), CPK: 3709 IU/L (26-140 IU/L), total protein: $6.2 \mathrm{~g} / \mathrm{dL}(6.1-8.4 \mathrm{~g} / \mathrm{dL})$, albumin: $2.6 \mathrm{~g} / \mathrm{dL}(3.5-5$ $\mathrm{g} / \mathrm{dL}$ ), phosphorus: $6.8 \mathrm{mg} / \mathrm{dL}(2.4-4.5 \mathrm{mg} / \mathrm{dL})$, calcium: $6.6 \mathrm{mg} / \mathrm{dL}(8.4-10.5 \mathrm{mg} / \mathrm{dL})$, PTH: $305 \mathrm{pg} / \mathrm{mL}(15-65 \mathrm{pg} / \mathrm{mL}) \mathrm{Hb}: 6.5 \mathrm{~g} / \mathrm{dL}$, WBC: $10800 / \mathrm{mL}$, platelet: $280000 / \mu \mathrm{L}$, arterial blood gas analysis, $\mathrm{pH}: 7, \mathrm{PCO} 2: 23 \mathrm{mmHg}, \mathrm{PO}_{2}: 47 \mathrm{mmHg}, \mathrm{HCO}: 5.8 \mathrm{mEq} / \mathrm{L}$, respectively. The complete urine examination showed proteinuria $(++)$, glucose $(++)$, ketones (-), and it was measured $5 \mathrm{~g} /$ day of micrototal protein level and $1 \mathrm{~g} /$ day of microalbumin levels for 24-hour urine. Autoantibodies levels including ANA, antidsDNA, p-ANCA, c-ANCA, antiGBM and $\mathrm{C} 3$ and $\mathrm{C} 4$ were normal limits.

The patient was admitted to the depertment of nephrology with diagnosis of acute renal failure (ARF), and emergency dialysis therapy was applied. She was given $0.2 \mathrm{mg} / \mathrm{kg} \mathrm{IV}$ diazepam during epileptic seizure and her oxcarbazepine doses was increased to 1200 $\mathrm{mg} /$ day by the proposals of neurology department for epileptic seizures. She was also examined by psychiatry because of agitated behaviors and, was given alprazolam 0.5 $\mathrm{mg} /$ day and citalopram $20 \mathrm{mg} /$ day. Fever reached $38.5^{\circ} \mathrm{C}$ on 3th day of hospitalization. Staphylococcus aureus was isolated from the patient's blood culture, and hemodialysis catheters were thought to be the source of infection. Ampicillin-sulbactam was started 3 $\mathrm{g} /$ day according to the result of the culture-antibiogramme, and fever disappeared within 48 hours, and it didn't rise again. The intermittent hemodialysis treatment was continued according to the patient's daily BUN, creatinine, electrolytes and blood gas results. After eight sessions of hemodialysis, blood creatinine level fell down to $5 \mathrm{mg} / \mathrm{dL}$, and remained stable around this level. The size of both in renal ultrasonographic examination were small and parenchymal echogenicity was increased (Grade 3). Thus, there was no need for renal biopsy. On the basis of these findings, the patient was diagnosed as acute renal failure from chronic renal disease due to NMS. The patient continuously needed hemodialysis treatment during the next follow-up, and was included in three days a week regular hemodialysis program.

\section{Discussion}

Diagnostic criteria for NMS were determined in 1985 by Levenson. While major criteria are fever, rigidity and high CPK level, the minor criteria are defined as tachycardia, tachypnea, sweating, blood pressure alterations, leucocytosis and changes in consciousness [13]. Three major criteria (fever, rigidity and CPK elevation) and 3 minor criteria (blood pressure changes, leucocytosis, changes in consciousness) were present in our patient. 
Neuroleptic malignant syndrome is common among young or middle aged adults, and usually it occurs within the first 10 days following the use of antipsychotic drugs, but also may occur at any stage of treatment as well $[14,15]$. The use of antiemetics, electrolyte disturbances (especially hypokalemia), environmental humidity and winter seasons (rarely) play a role in the etiology [16]. Doğan et al. [17] detected hypokalemia in one of their 3 cases. They reported appearance of NMS accompanied by the use of metoclopramide and pointed out the relation between winter season in the geographic region and the development of NMS because each of 3 patients were subjected to intense cold environment. The NMS cases arise by antidepressants such as amoxapin, venlafaxin and central nervous system stimulant drugs like methylphenidate as well as neuroleptic according to the publications [18-20]. Also, Pinar et al. [21] have reported a case with NMS due to poisoning by the herbicide called trifluraline. Martinez at al. [22] have reported NMS after phenytoin treatment of epilepsy in a 9-year-of child. In addition, the relatives of our 40 years old patient also mentioned the use of same long-term treatment (300 mg/day oxcarbazepine, phenytoin $200 \mathrm{mg}$ /day, clonazepam $2 \mathrm{mg} /$ day).

Other risk factors described for the NMS are the use of lithium, dehydration, nutritional deficiencies, high-dose and long-term use of antipsychotic drugs with the use of antipsychotics, history of previous NMS, the presence of organic brain disease and previous treatment of electroconvulsive therapy [23-25]. Our patient frequently had a febrile illness in her infancy, and mental retardation determined by psychiatric evaluation. This also supports the possible organic brain disease which is a risk factor for NMS as described above. Moreover, two patients with mental retardation was diagnosed with NMS by Turan et al. [26] Only in one patient high fever, convulsions and dullness were observed after initiation of haloperidol and biperiden therapy. The clinical status improved subsequently after hospitalisation and the initiation of appropriate treatment. Besides the history of difficult birth, family conversations also unveiled that she had the febrile illness and convulsions when she was 3 month. In other case, mistakenly applied larger dose fluphenazine treatment resulted in the beginning of contractions, shivering, sweating, high fever and difficulty in swallowing after 5 days. This hospitalized NMS case who developed ARF due to uric acid nephropathy during treatment was reported to receive hemodialysis treatment for 2 times. They have reported that NMS symptoms and ARF improved after the treatment described above. After meeting the family of the patient, history of frequent exposure to febrile disease during infancy and childhood was also noted. The detection of mental retardation in both cases suggests that mental retardation may be a risk factor for NMS [26]. Renal biopsy specimens of another case with NMS demonstrated uric acid crystals which play a major role in the pathogenesis of acute renal failure due to rhabdomyolysis [27].

In another case report, Diamond et al. [28] claimed that organic brain disease and mental retardation may be risk factors in a case of NMS leading to a coma induced by injection of fluphenazine in a 16-year-old adolescent with mental retardation, such patients ought to be followed-up in a more strict fashion. In the literature, mental retardation especially has been reported to be a relative risk for recurrent NMS. Mortality and morbidity rate are high among the NMS patients with mental retardation [29]. Acute renal failure develops in $16 \%$ of all cases of NMS and mortality increases by approximately $50 \%$ [30, 31].

In conclusion, a long-term neuroleptic medication use was the risk factor for the development of the NMS in our case. However, the existence of mental retardation may be an another additional risk factor as suggested by the literature above.

\section{References}

1. Delay J, Pichot P, Lemperiere T, Elissalde B, Peigne F. A non-phenothiazine and non-reserpine major neuroleptic, haloperidol, in the treatment of psychoses. Ann Med Psychol (Paris) 1960; 118: 145-52.

2. Kaplan HI, Sadock BJ, Grebb JA. Synopsis of Psychiatry, 7th Edition, Baltimore, 
Williams\&Wilkins, 1994; pp: 953.

3. American Psychiatric Association. Diagnostic and Statistical Manual of Mental Disorder. 4. Bask1 (DSM-IV)Washington DC, American Psychiatric Association 1994; s: 739-42.

4. Nisijima K, Ishiguro T. Cerebrospinal fluid levels of monoamine metabolites and gamma-aminobutyric acid in neuroleptic malignant syndrome. J Psychiatr Res 1995; 29: 233-44.

5. Ueda M, Hamamoto M, Nagayama H, Okubo S, Amemiya S, Katayama Y. Biochemical alterations during medication withdrawal in Parkinson's disease with and without neuroleptic malignant-like syndrome. J Neurol Neurosurg Psychiatry 2001; 71: 111-3.

6. Keck PE Jr, Pope HG Jr, Cohen BM, McElroy SL, Nierenberg AA. Risk factors for neuroleptic malignant syndrome. A case-control study. Arch Gen Psychiatry 1989; 46: 914-8.

7. Berardi D, Amore M, Keck PE Jr, Troia M, Dell'Atti M. Clinical and pharmacologic risk factors for neuroleptic malignant syndrome: a case-control study. Biol Psychiatry 1998; 44: 748-54.

8. Strawn JR, Keck PE Jr, Caroff SN. Neuroleptic malignant syndrome. Am J Psychiatry 2007; 164: 870-6.

9. Bambrick M, Wilson D. Recurrent neuroleptic malignant syndrome in a man with mild mental handicap. J Intellect Disabil Res 1992; 36: 377-81.

10. Margetic B, Aukst-Margetic B. Neuroleptic malignant syndrome and clozapine withdrawal at the same time? Prog Neuropsychopharmacol Biol Psychiatry 2005; 29: 145-7.

11. Caroff SN, Mann SC. Neuroleptic malignant syndrome. Med Clin North Am 1993; 77: 185-202.

12. Stübner S, Rustenbeck E, Grohmann R, Wagner G, Engel R, Neundörfer G, Möller HJ, Hippius H, Rüther E. Severe and uncommon involuntary movement disorders due to psychotropic drugs. Pharmacopsychiatry 2004; 37(suppl 1): S54S64.

13. Levenson JL. Neuroleptic malignant syndrome. Am J Psychiatry 1985; 142: 1137-45.

14. Harrigan RA, Brady WJ. Antipsychotics. In: Tintinalli JE, Kelen GD, Stapczynski JS, editors. Emergency medicine.5th ed. New York: McGraw-Hill Companies 2000; pp: 1086-7.

15. Gelder M, Gath D, Mayou R,Cowen P. The neuroleptic malignant syndrome. In: Gelder M, Gath D, Mayou R,Cowen P,editors. Oxford textbook of psychiatry.3rd ed. Oxford University New York 1996; 162-184

16. Patterson JF. Neuroleptic malignant syndrome associated with metoclopramide. South Med J 1988; 81: 674.

17. Doğan N, Kürşad H, Erdem AF, Kızılkaya M. Nöroleptik malign sendromda nadir etyolojik faktörler ve klinik seyir. Atatürk Üniversitesi Tıp Dergisi 2003; 35: $23-6$.

18. Nimmagadda SR, Ryan DH, Atkin SL. Neuroleptic malignant syndrome after venlafaxine. Lancet 2000; 355(9200): 289-90.

19. Gupta S, Racaniello AA. Neuroleptic malignant syndrome associated with amoxapine and lithium in an older adult. Ann Clin Psychiatry 2000; 12: 107-9.

20. Ehara H, Maegaki Y, Takeshita K. Neuroleptic malignant syndrome and methylphenidate. Pediatr Neurol 1998; 19: 299-301.

21. Pınar ÇE, Gedizlioğlu M. Neuroleptic malignant-like syndrome due to herbicide intoxication. J Neurological Sciences 2005; 22: 101-3.

22. Martínez HR, Cantú-Martínez L, González HC, Flores Lde L, Villarreal HJ, Onofre-Castillo J. Epilepsy, parkinsonism, and neuroleptic malignant syndrome in a child. J Child Neurol 2006; 21: 1073-5.

23. Naganuma H, Fujii I. Incidence and risk factors in neuroleptic malignant 
syndrome. Acta Psychiatr Scand 1994; 90: 424-6.

24. Addonizio G, Susman VL, Roth SD. Neuroleptic malignant syndrome: review and analysis of 115 cases. Biol Psychiatry 1987; 22: 1004-20.

25. Sachdev P, Mason C, Hadzi-Pavlovic D. Case-control study of neuroleptic malignant syndrome. Am J Psychiatry 1997; 154: 1156-8.

26. Turan M, Kucur R. Nöroleptik malign sendrom ve mental retardasyon: İki olgu sunumu. Klinik Psikiyatri 2001; 4: 134-7.

27. Özdemir FN, Kayataş M, Demirhan B, Güz G, Haberal M :The role of uric asid crystallization in acute renal failure due to rhabdomyolysis developing after neuroleptic malignant syndrome" Acute Renal Failure-Towards 2000, Cairns Convention Centre, Cairns, Australia 1- 3 June 1997 (Abstract Book)

28. Diamond JM, Hayes DD. A case of neuroleptic malignant syndrome in a mentally retarded adolescent. J Adolesc Health Care 1986; 7: 419-22.

29. Boyd RD. Neuroleptic malignant syndrome and mental retardation: review and analysis of 29 cases. Am J Ment Retard 1993; 98: 143-55.

30. Shalev A, Munitz $\mathrm{H}$. The neuroleptic malignant syndrome: agent and host interaction. Acta Psychiatr Scand 1986; 73: 337-47.

31. Korzets Z, Zelter E, Bernheim J. Acute renal failure in the setting of the neuroleptic malignant syndrome. Nephrol Dial Transplant 1996; 11: 885-6. 